\title{
COSMOGONY IN THE PERSPECTIVE OF THE PROPHET OF MUHAMMAD'S UTTERANCES
}

\author{
Danusiri \\ UIN Walisongo Semarang \\ Email: danusiri.29@gmail.com
}

\begin{abstract}
The study reports on a version of the cosmogonic information amidst the various chronicle stories of the world's great tribes. The Prophet Muhammad's version of cosmogony has dimensions of transcendentalism. The version also contains the actual value of the Islamic faith, rather than just a myth. The study uses qualitative with library research, and the data were sourced from nine standard hadith books, at digital 'Lidwa Pustaka-I' Software 'Kitab 9 Imam Hadith' (2009). The study applied thematic and chronological methods to describe how the universe has begun, created a shape until the end of its existence. Allah has created the universe from 'nothing' into 'existence'. Based on His mercy, pre-designed was pitch black at the beginning of the world's creation. Light arose simultaneously with the process of the occurring part of the universe. The findings reveal that the entire contents of the universe designated as facilities for life where the earth is helpful for human life. At one point, nature will shrink because Allah grasps it, the layout of every celestial body changes completely, and its aftermath is unknown to humans.
\end{abstract}

Keywords: cosmogony, perspective, utterances of the Prophet

Abstrak: Kajian ini melaporkan informasi pada sebuah versi kosmogonik di tengah berbagai kisah kronik suku-suku besar dunia. Kosmogoni versi Nabi Muhammad SAW memiliki dimensi transendentalisme. Versi tersebut juga memuat nilai aktual dari akidah Islam, bukan sekedar mitos. Penelitian ini menggunakan kualitatif dengan studi kepustakaan, dan data bersumber dari sembilan kitab hadis standar, pada software digital 'Lidwa Pustaka-I' 'Kitab 9 Imam Hadith' (2009). Kajian ini menerapkan metode tematik dan kronologis untuk menggambarkan bagaimana alam semesta dimulai, diciptakan dan dibentuk hingga akhir keberadaannya. Allah telah menciptakan alam semesta dari 'tidak ada' menjadi 'ada'. Berdasarkan rahmat-Nya, pra-desain dalam keadaan gelap gulita pada awal penciptaan dunia. Cahaya muncul bersamaan dengan proses terjadinya alam semesta. Temuan penelitian ini mengungkapkan bahwa seluruh isi alam semesta ditetapkan sebagai fasilitas kehidupan dan bumi bermanfaat bagi kehidupan manusia. Pada suatu saat, alam akan menyusut karena Allah menggenggamnya, tata letak setiap benda angkasa berubah total, dan akibatnya tidak diketahui manusia.

Kata-kata kunci: kosmogoni, perspektif, sabda Nabi 


\section{Introduction}

Allah sent Prophet Muhammad to this world as a blessing for the universe. ${ }^{1}$ The effects of grace for those who get it can manifest, among others: pleasure, satisfaction, serenity, and happiness because the lexical meaning of grace itself is love. ${ }^{2}$ As a bearer of mercy, Prophet Muhammad had words, actions, and provisions that could all be referred to as the traditions of the Prophet. ${ }^{3}$ The Prophet's sunnah is a way of life for Moslems in addition to the Qur'an. ${ }^{4}$

In practical terms, the Prophet's hadiths have been documented in an orderly and systematic manner in the form of hadith books. Ulama consider nine classic hadith books from many perspectives - 'Ŝạiih al-Bukhari,' 'Ŝahíih, al-Muslim,' 'Sunan Abu Dawud,' 'Sunan at-Turmuzi,, 'Sunan Ibnu an-Nasâ'I,' 'Sunan Ibnu Mâja'h, 'Musnad Imam Ahmad,' 'Sunan ad-Darim'i, dan 'Muwaththa' Malik.'

This paper needs to explain two terms: 'cosmogony' and 'utterance of the Prophet. The word "cosmogony" comes from the Greek "cosmos" and "gonai". Combining these two words becomes 'cosmogony', which means creation. ${ }^{5}$ In primitive cultures of the world's significant ethnicities usually have several cosmogonic mythologies, ${ }^{6}$

The world comes from a single substance such as water, air, chaos, eggs, gigantic bodies, something abstract and spiritual or divine. The world is created slowly (through evolution) and is periodically toward its perfection with annual calculations. ${ }^{7}$ as air separates from water for 100 years.

The definition of "cosmogony" can be likened to "cosmology." 8 The meaning of cosmology itself is a branch of philosophy that studies the origins and structure of the world (universe). ${ }^{9}$ In this sense, cosmology is a branch of metaphysics and differs from ontology, theology, and psychology. ${ }^{10}$ So, in philosophical systematics, metaphysics is a branch of cosmology, and on the other hand, cosmology is a branch of metaphysics. Thus it can be understood that cosmogony can also be said to be a branch of philosophy.

The similarity of understanding implies that cosmogony is a speculative philosophy about the universe. ${ }^{11}$ The universe here is the real stars, planets, satellites, or the systemization of humans, in this case, philosophers or thinkers, regarding the sun and the stars as a whole. ${ }^{12}$ The universe can also be interpreted as "the whole system of existing things, all existing view whole as one whole, the world." 13 So, what is meant by the universe here is material, which in the language

\footnotetext{
${ }^{1}$ Anonim, Al-Qur'ân Al-Karím, Departemen Agama Republik Indonesia: Sygma Examedia Arkanleema. Bandung, 2017, QS. Al-Anbiyâ'/21, p. 107.

${ }^{2}$ Ar-Raghib al-Ashfahani, Mufradât Alfâz al-Qur'ân, (Damsik-Beirut: Dar al-Qalam-Dar alIslamiyyah, 1992), p. 348.

${ }^{3}$ Shubhi Shalih, 'Ulūm al-Hadîs wa Mushthalâhuhu, (Beirut:al-'Ilm al-Malayín, 1988), pp. 3-4.

${ }^{4}$ Anonim, Al-Qur'ân Al-Karím, Departemen Agama Republik Indonesia: Sygma Examedia Arkanleema. Bandung, 2017, QS.Al-Hasyr/59, p. 7.

${ }^{5}$ Dagobert de Runes, Dictionary of Philosophy, (Totowa-New Jersey: Littlefield-Adams \& Co., 1976), p. 68.

'Since now and then, 'cosmogony' in Bahasa Indonesia has been written as 'kosmogoni.'

${ }^{7}$ Ibid.,

${ }^{8}$ Paul Edwards, The Encyclopaedia og Philosophy, (New York: Collier Macmillan Publishers, 1972), Vol. VII, p. 232.

${ }^{9}$ Dagobert de Runes, loc. cit.

${ }^{10}$ Edwards, op cit., p. 237.

${ }^{11}$ Ibid., p. 238.

${ }^{12}$ A.S. Hornby, Oxford Advanced Learning Dictionary of Current English, (t.t.: t.p., t.th.), p. 961.

13"Webster's New Dictionary and Thesaurus, (USA [United States of America]: Geddest \& Grosset Ltd., 1990), p. 591.
} 
Danusiri

of the Qur'an is 'as-samâwât wa al-ard,' namely space objects, and space between these objects, different from the meaning of al-'alamín. This word implies 'alkhalqu kulluh.' ${ }^{14}$, including al-'arsy, heaven, hell, angels realm, 'barzah' realm, 'alma'mūr,' 'thuba,' 'al-haud,,' 'sidratul muntaha,' 'rafraf,' pulpit, and chairs, all of which are immaterial and can be depreciated. As-samâwât wa al-ard is just one of 18,000 al-'alâm. ${ }^{15}$ The term cosmogony is the origin and structure of the universe and its material. Cosmogony is equated with the cosmological concept with the transcendental method, with the following explanation:

"The transcendental method starts from the most central human phenomena and activities such as thinking, speaking, and choosing do not analyze the meanings and values. The values are expressed as explicit content rather than implicit assumptions or absolute conditions that allow the implementation of these facts. The assumptions are found both on the subject itself, which acts, and the object involved.

Thus, at this stage, the Prophet, in delivering his message, was based on the Qur'an and hadiths, and it is ${ }^{16}$ equivalent with philosopy. ${ }^{17}$ In terms of religion, what was said by the Prophet, instead of conceptual matters regarding the Qur'an, surah an-najm / 53: 3-4 is revelation. The process of revelation usually takes place when the human self is in the most central state diving into the deepest recesses.

In the case of the revelation experienced by Prophet Muhammad, who was in such a state, Orientalists misinterpreted that the Prophet had epilepsy. ${ }^{18}$ So, if the point of view of the Prophet Muhammad was started from a human phenomenon, he was an ordinary human being who became a philosopher. However, in a religious perspective, Muhammad is both a Prophet and a Messenger. Consequently, what he says about the universe's origin until its extinction can be called cosmogony or transcendental cosmology.

Viewing the Prophet Muhammad as a philosopher gives the possibility of being wrong in his philosophers' speculations. It is undoubtedly a problem for someone's Islamic faith to the Prophet. However, it should be realized that separating which of his utterances is a reflection of philosophical speculation and which words reflect his prophetic treatise on the origin, the structure of the universe, and its extinction is extremely difficult or even impossible. Therefore, the Prophet's speculations about the cosmogony are entirely correct because these reflections essentially also arise from prophetic experience, the deepest recesses of the Prophet's self-awareness.

\section{Utterances of the Prophet}

The utterances of the Prophet are part of the scope of the Prophet's hadith or sunnah, which contain words, deeds, and 'taqrir' (approval or rejection) and the condition of the Prophet. ${ }^{19}$

14Ibrahim Anis., et all, al-Mu'jam al-Wasith, (Istambul: Al-maktabah Al-Islamiyyah, [t.th.], II, p. 642; Jamâl ad-Dín Muhammad Ibn Mukarram al-Anshari Ibn Mandhur, Lisan al-'Arab, (Qahirah: Dar Al-Mishriyyah li at-Ta'lif wa at-Tarjamah, 1990), XII, pp. 420-421.

${ }^{15}$ Ar-Raghíb, al-Ashfahâni, op cit., p. 582.

${ }^{16}$ Anonim, Al-Qur'ân Al-Karím, Departemen Agama Republik Indonesia: Sygma Examedia Arkanleema. Bandung, 2017, QS. Al-Baqarah/2:129, 151, 231; Ali Imran/3:48, 164; an-Nisâ'/4:54, 113; al-Maidah/5:110.

${ }^{17}$ Musa Asy'arie, Filsafat Islam: Sunnah Nabi Dalam Berpikir, (Yogyakarta: LESFI [Lembaga Studi Filsafat Islam], 1999), p. 20.

${ }^{18}$ Fazlur Rahman, Islam, (Chicago-London: University of Chicago Press, 1966), p. 13.

${ }^{19}$ Maḥmūd ath-Thaḥan, Taisír Mushthalaḥul Hadís, (Beirut: Dâr aŝ-Ŝaqafahal-Islamiyyah, [t.th.]), p. 12. 
Based on the Prophet's view of 'cosmogony' and 'utterances,' this paper reveals the utterances of the Prophet concerning the origin, structure of the universe, and its extinction. The main problem in this paper is the concept of cosmogony in the Prophet's utterances. This study aims to find out the Prophet's utterances regarding cosmogony and provide information to academic community who are interested in philosophy, cultural anthropology, or even the general public. The researcher assures the reader that the Prophet Muhammad's version of cosmogony is guaranteed to be confirmed based on faith because what he says is a revelation from Allah the Almighty.

If we examine the cosmogonic descriptions of the various beliefs of the tribes in the world, the universe's origin includes the earth has various explanations. All of them, of course, there is no guarantee of correctness based on a review of any philosophical or scientific discipline except based on the beliefs of the people concerned. Meanwhile, the Prophet's version of cosmogony contains the beliefs of particular communities, and it has religious truth across ethnicities and nations because Islam has spread on this earth. So, this description of the Prophet's version of cosmogony can provide insight into the concept of cosmogony to all Moslems in the world. The concept of cosmogony in the version of the Prophet's utterances has synergy with the Quran, even for certain parts, is a further explanation of what the Quran explains.

This study is qualitative and the data were taken in form of takhríj al-hadis of hadith kitab (books), namely: 'Shahịh Bukhariy', 'Shahíh Muslim', 'Sunan Abi Dawud', 'Sunan at-Turmuzi', 'Sunan Ibnu Mâjah', 'Sunan an-Nasâ'i', 'Musnad Ahmad bin Hanbal', 'Muwaththa' Mâlik', and 'Sunan ad-Darimi' in form of digital (Lidwa Pustaka-i Software Kitab 9 Imam Hadist 2009). The words 'takhrij hadith' by narrator meant as 'Khalaqa', 'badi'a', 'ja'ala', and 'fathara', 'As-samâwât wa al-ard, al-mâ', 'ad-dukhan', 'al-jibâl', 'as-Sara', 'Ǎdam', and 'al-qiyamah'. These words include their derivatives, from the word 'ja'ala' to 'yaj'alu,' which means "create." All the hadiths quoted in this study are 'shahih' (authentic), as seen in the complete research report. ${ }^{20}$ This research is in the form of verbal expressions, and it was analyzed at the stage of data collection, as suggested by Milles and Huberman. ${ }^{21}$ The results of the discussion from each chapter were formulated in various statements since the analysis and data interpretation method because when constructing data, in essence, interpreting the data. The choice of such a method leads to the $11^{\text {th }}$ inferring tactic technique suggested by Milles and Huberman, namely constructing a logical link between various evidence. ${ }^{22}$

Prophet Muhammad stated that the universe was created by Allah اللَّهُ خَالِقُ كُلِّن شَيْءٍ (Allah is the creator of all things) which 'khalaqa', 'yakhluqu khâliqun' as the synonyms, and the words 'fathara', 'yafthiru,' 'fâthirun' are examples in the 'matan:

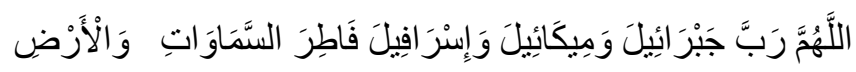

20Danusiri, Kosmogoni Dalam Perspektif Sabda Nabi, (Semarang: IAIN Walisongo, 2014) research funded by DIPA IAIN Walisongo Semarang.

${ }^{21}$ Matthew B. Milles, A Michael Huberman, Qualitative Data Analysis, translated by Tjetjep Rohandi entitled: Analisis data Kualitatif, (Jakarta: Universitas Indonesia, 1992), pp. 86, 105, 111, 116.

${ }^{22}$ Ibid., p. 118; Noeng Muhadjir, Metodologi Penelitian Kualitatif, (Yogyakarta: Rakesarasin, 1994), 3rd ed, p. 27 
The translation: 0 Allah, Lord of 'Jibril, Mika'il, and Israfil'; The Almighty, The Creator of Heavens and Earth), and 'badi'a, yabdi'u, badi'un,' as in matan:

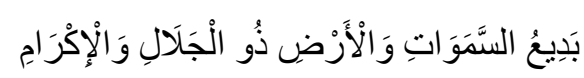

Translation: The Creator of heaven and earth, The Most Noble and The Most Generous.

The term 'khalaqa' means 'at-taqdir' 'al-mustaqim' (certainty that is absolutely certain), 'ibda' asy-syai' min ghairi ashl wala ihtiza'in' (creation of things is not from origin and not quickly), so it is evolutionary 'badalah' (changes), that is, something to become heaven and earth is through a process of change, and ijadu syai' min syai'. (manifest something from something). The examples of 'khalaqa' are as in 'khalaqakum min nafsin wâhidah' (I created you all from one-self) 'khalaqa alinsâna minal muthghah', (who created man from a lump of flesh), and 'khalaqa aljanna min mârijin mi an-nâr' (He created the 'jinns' from smokeless flames).

The term 'fathara' means 'asy-syaqq' (tear, split), and 'ibtida' wakhtira'uhu' (beginning of its creation). 'Fatharallahul 'alam' means Allah started and created the universe. Another meaning of the word 'fathara' is 'asy-syaqqa ath-thūl' (lengthwise split). For example, the result of splitting bamboo is the length of the bamboo. Each split is different and the same at once, that is, both have a base and an end. The meaning in the Quran is shown "Hal tara min futhūr" (Do you notice anything unbalanced?) which means, the result of Allah's creation by using the word 'fathara': there will be a balance and the balance is the basis of life.

The term 'badi'a' when applied to Allah means 'ijaâdu asy-syai' bighairi âlâtin walâ zamânin walâ makânin' (creating something without tools, time, or place). When compared to the two previous models, those are the words 'khalaqa' and 'fathara' which mean evolutionary creation, the word 'badi'a' means revolutionary model, very fast exceeding the speed of the blink of an eye (lamhul bashar). ${ }^{23}$

Ibn Sina, al-Farabi, and ar-Razi (Moslem philosophers), said that the universe comes from the first material. In the philosophy of emanation, it is stated that:

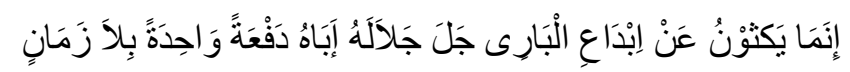

Translation: universe occurs through creation at once without time by God Almighty) ${ }^{24}$.

This creation at the same time took place the first sense to the ninth sense, and the stars: the fixed stars, Saturn, Jupiter, Mars, the sun, Venus, Mercury, and the Moon. All these forms are not yet in material form. The first material-tangible creation was earth on the basis of the aggregate among earth, water, air and fire. ${ }^{25}$ Thus the contradictio-intermini in the creation concept of the Prophet's version can be explained through the creation concept of Moslem philosophers, that creation from the first incarnation to the 10th uses the 'badi'a,' creation model, then the next creation, that is 'universum', using the 'khalaqa' and 'fathara' models.

${ }^{23}$ Anonim, Al-Qur'ân Al-Karím, Departemen Agama Republik Indonesia: Sygma Examedia Arkanleema. Bandung, 2017, QS. an-Nahl/16:77; al-Qamar/54:50.

${ }^{24}$ Harun Nasution, Falsafah dan Mistisisme Dalam Islam, (Jakarta: Bulan Bintang, 1978), p. 29.

${ }^{25}$ Ibid., pp. 27-28. 
The purpose of the epistemology of creation is the description of how this universe proceeds. The heavens and the earth were created by Allah on the basis of mercy (His mercy). The Messenger said:

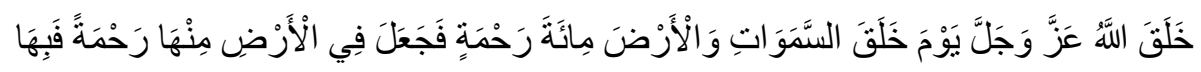

Translation: On the day when 'Allah' azza wajalla' created the Heavens and the Earth, He created one hundred (degrees of) mercy, of which He placed one on earth. ${ }^{26}$

Presumably, only Islam states that this universe was created on the basis of the love of the creator. The messenger (Rasulullah) said that before taking action to create, Allah is committed that compassion precedes His wrath. Thus the Prophet said:

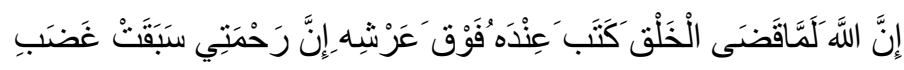

Translation: When Allah completed the creation, He wrote in His Book which is with Him on His Throne, "My Mercy overpowers My Anger". 27

Rasulullah SAW says:

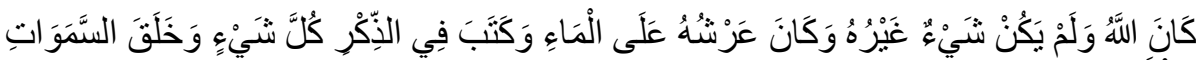

$$
\begin{aligned}
& \text { وَالْأْرَضْنَ }
\end{aligned}
$$

Translation: "First of all, there was nothing but Allah, and (then He created His Throne). His Throne was over the water, and He wrote everything in the Book (in the heaven) and created the Heavens and the Earth)."28

Before taking action to create, Allah first conceptualizes creation. Thus, the Prophet said:

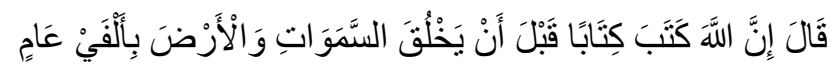

Translation: "Allah wrote His Book (Quran) two thousand years before He created the Heavens and the Earth. ${ }^{29}$

It is certain that the unit of time referred to in the Prophet's words is not the duration on this earth because the earth has not yet materialized. In general, it is called the 'azali' era that is the time before any creatures exist. Iqbal calls it as the absolute present time or a single 'now' which cannot be divided into the past, present and future. ${ }^{30}$ There is a condition that Allah has existed and always exists

${ }^{26}$ HR Muslim: 4943, 4944, 4945, 4946, at-Tumuzi: 3464, Ibnu Majah: 4283, 4284, Ahmad: $8063,9236,9890,10256,10390,11104,11105,18046$, and 22605.

${ }^{27}$ HR Bukhari: 6872, 6898, 6998, 6999, Muslim: 4940, Ibnu Majah: 185, Ahmad: 6998, 7187, 7215, 8601, 8794, 9633.

${ }^{28}$ HR Bukhari: 2952 and 2953.

${ }^{29}$ HR Darimi: 3253, Ahmad: 17688.

${ }^{30}$ Muhammad Iqbal, The Reconstruction of Religious Thought in Islam, (Lahore: Kitab Bavan, 1981), p. 48. 
but the universe does not exist, neither is the heavens and the earth (universes). Thus, the Prophet said:

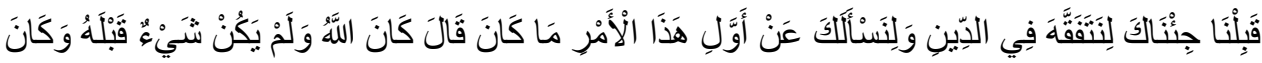

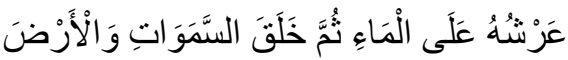

The translation: We have come to you to learn the religion, so we ask you what the beginning of this universe was. The Prophet SAW said "There was Allah and nothing else before Him and His Throne was over the water, and He then created the Heavens and the Earth and wrote everything in the Book."31

Lately, the theory of creation of the 'mutakallimun' "from nothing into being" (minal 'adam ilal wujūd or creatio ex nihillo) ${ }^{32}$ emerged. Water as a Basic Material for the Creation of Heaven and Earth When asked by Abu Hurairah, from what مِنْ الََْاءِ (from water). ${ }^{33}$ Rasulullah said that the initial state of creation was dark. He said:

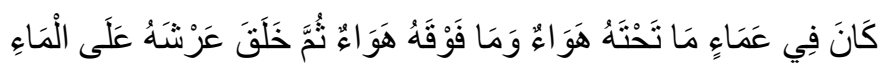

Translation: He was above the clouds - no air was under Him, no air was above Him, and He created His Throne upon the water. ${ }^{34}$ In a fairly long explanation, the Prophet said:

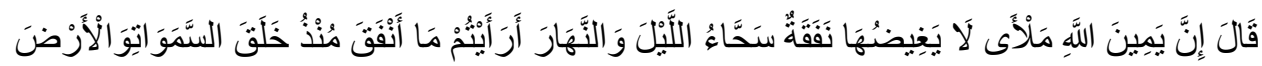

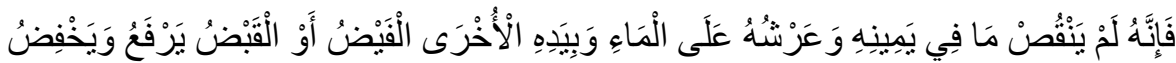

(Allah's Hand is full, and (its fullness) is not affected by the continuous spending, day and night. He also said, "Do you see what He has spent since He created the Heavens and the Earth? Yet all that has not decreased what is in His Hand." He also said, "His Throne is over the water and in His other Hand is the balance (of Justice) and He raises and lowers (whomever He will)."). ${ }^{35}$ In the 'mufassirun' tradition, every physical depiction of Allah is 'takwil' to purify Allah, for example the phrase "hand of Allah on their hands" means that they, the Moslems, pledge allegiance to the Prophet which is tantamount to pledging allegiance to Allah, or linking the hearts of their hearts to Allah. ${ }^{36}$ With this promise, it strengthens the understanding that "the servant will never stop drawing close to Allah with his main deeds until Allah loves him. When I (Allah) love him, I am his hearing by which he hears and I (Allah) am his hand by which he grasps. ${ }^{37}$ The Creation of Earth:

31HR Bukhari: 6868.

${ }^{32}$ Dagobert de Runes, Dictionary of Philosopy, (Totowa-New Jersey: Littlefield-Adams \&Co., 1976), p. 70

${ }^{33} \mathrm{HR}$ Turmuzi: 2449.

${ }^{34}$ HR Ahmad: 15599.

${ }^{35} \mathrm{HR}$ Bukhari: 6869.

${ }^{36}$ Sayyid Quthb, Tafsir Fi Zhilalil Qur'an, X, (Jakarta: Gema Insani), p. 379

${ }^{37}$ Ar-Raghib al-Asfahâni, Mufradât Alfâdh al-Qur'ân, (Damsyiq-Beirut: Dar al-Qalam-dar asSa'adah, 1996), p. 891 


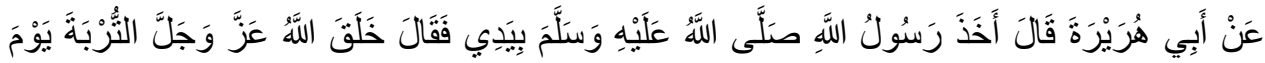

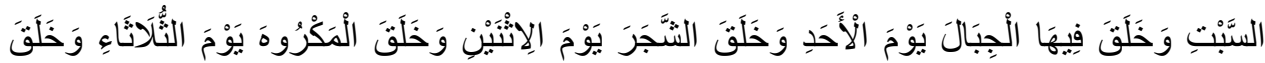

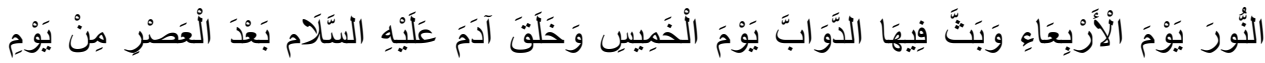

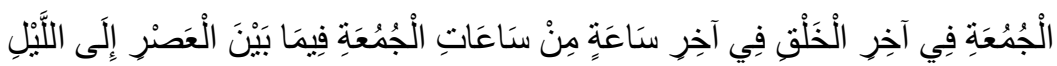

Abu Huraira reported that Allah's Messenger (Rasululah SAW) took hold of my hands and said, "Allah, the Exalted and Glorious, created the clay on Saturday and He created the mountains on Sunday and He created the trees on Monday and He created the things entailing labour on Tuesday and created light on Wednesday and lie caused the animals to spread on Thursday and created Adam (peace be upon him) after 'Asr' on Friday; the last creation at the last hour of the hours of Friday, i.e. between afternoon and the night." 38

Human as the Most Potential Creatures on Earth The Prophet said:

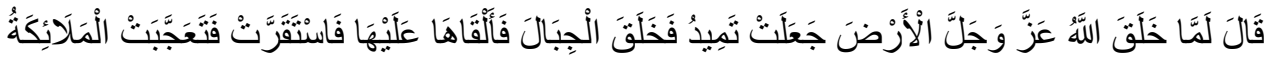

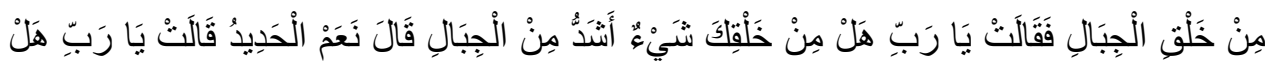

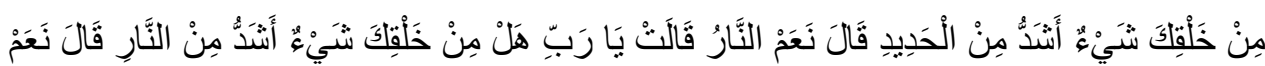

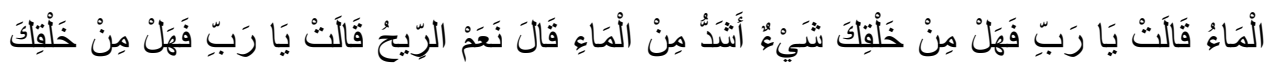

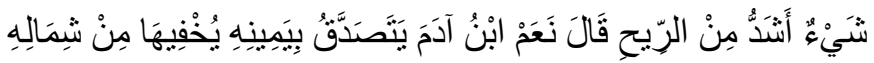

"When Allah created the earth, it started shaking. So He created the mountains, and said to them: "Upon it so it began to settle. The angels were amazed at the strength of the mountains, so they said: "O Lord! Is there among your creatures one who is more severe than the mountains?' He said: "Yes. Iron.' They said: "O Lord! Then is there anything among your creatures that is more severe than iron?' He said: "Yes. Fire.' They said: "O Lord! Is there anything among your creatures that is more severe than fire?' He said: "Yes. Water.' They said: 0 Lord! Is there anything among your creatures that is more severe than water?' He said: "Yes. Wind.' They said: "O Lord! Is there anything among your creatures that is more severe than wind?' He said: "Yes. The son of Adam. He gives charity with his right hands, while hiding it from his left." 39

Part of the Earth is Purified, the day after conquering Mecca, the Prophet made a long speech, among other things, he said:

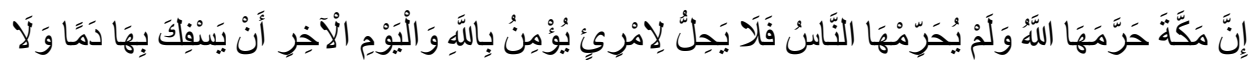

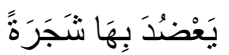

${ }^{38}$ HR. Muslim: 4997, Ahmad: 7991.

${ }^{39}$ HR. Ahmad: 11805. 
Allah and not the people has made Mecca a sanctuary. So anybody who has belief in Allah and the Last Day (i.e. a Muslim) should neither shed blood in it nor cut down its trees. ${ }^{40}$ The Whole Earth is a Masjid (Mosque), the Prophet said:

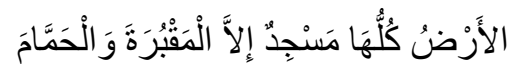

"All of the earth is a Masjid except for the graveyard and the washroom." 41

Allah as King, Preserver, and Ruler of Heaven and Earth, After the heavens and the earth have been established as can be witnessed by humans living in any generation, the Messenger of Allah declared that Allah is the king, preserver, and sole ruler in the universe, including its heaven and earth. All submit to Him. He prayed in which there was an acknowledgment that Allah is the king of the universe. Here's the prayer:

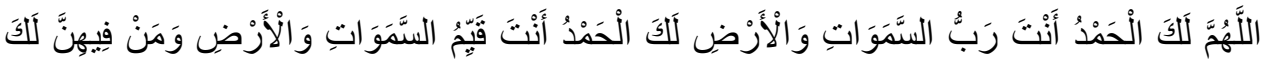

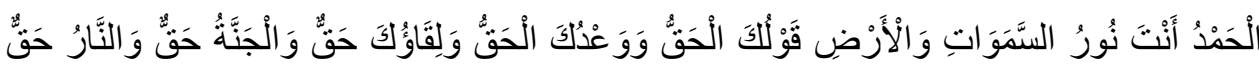

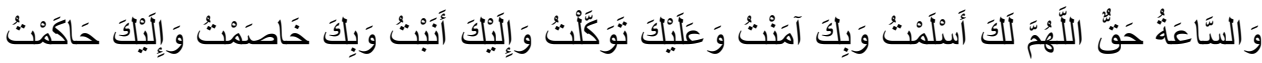

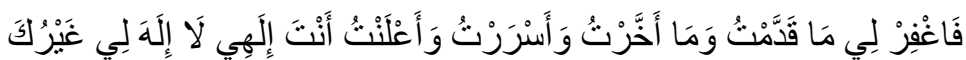

O Allah! All the praises are for You, You are the Holder of the Heavens and the Earth and whatever is in them. All the praises are for You; You are the Light of the Heavens and the Earth and all the praises are for You; You are the King of the Heavens and the Earth; And all the praises are for You; You are the Truth and your Promise is the truth, and to meet You is true, Your Word is the Truth and Paradise is true and Hell is true and all the Prophets (Peace be upon on them) are true, and Muhammad is true, and the Day of Resurrection is true. O Allah! I surrender (my will) to You; I believe in You and depend on You. And repent to You, and with Your help I argue (with my opponents, the non-believers) and I take You as a judge (to judge between us). Please forgive me my previous and future sins; and whatever I concealed or revealed and You are the One who make (some people) forward and (some) backward. There is none to be worshipped but You. ${ }^{42}$

Benefits of the Universe when someone asked the Prophet Muhammad about the benefits of the universe, he replied, Allah. It means, Allah made this universe a facility for human life. The following is the hadith:

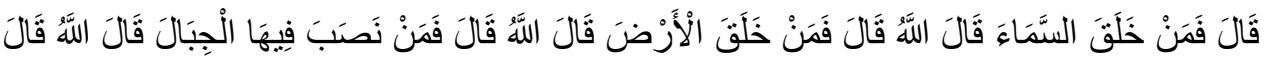

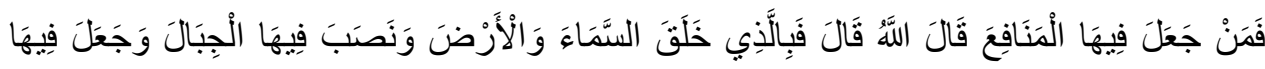

$$
\begin{aligned}
& \text { الْمَنَافِعَ آلَّهُ }
\end{aligned}
$$

Who had created Heavens? He (The Prophet Muhammad SAW) answered, Allah. He asked, Who had established mountains? He (The Prophet Muhammad

${ }^{40}$ HR. Bukhari: 1071, 101, 3957, 1701, Muslim: 2413, An-Nasai: 2827, Ahmad: 15778, 15781, and 25911.

${ }^{41}$ HR. Tirmuzi: 317, Ibnu Majah: 745, Darimi: 1390.

42HR. Bukhari: 1053, 5842, 5837, 6888, 6945, Malik: 451, Ibnu Majah: 1345, Muslim: 1288, Abu Dawud: 655, Turmuzi, 3340, An-Nasai, 1601, Ahmad, 2575, 2673, 3196. 
SAW) said, Allah. He asked, Who had given so many benefits in it? He (The Prophet Muhammad SAW) said, Allah.

From the Prophet's answer to this questioner, 'rajulun', someone, it can be understood that any object in this universe, including the laws that apply in it, is a facility for human life because there must be benefits. Of course, humans must know how to use it, for example fire for lighting and cooking, water for drinking, bathing, agricultural irrigation and power generation, etc. In short, the Quran explains that whatever is on earth is for the needs of human life. Allah says:

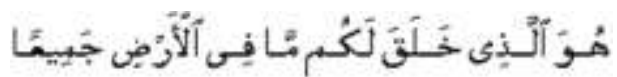

(It is He who created for you all of that which is on the earth).

Doomsday, Islam believes in 'kiyamat' (doomsday), which is marked by the destruction of the universe. That is why this realm will end. The Messenger described the destruction of universe as follows:

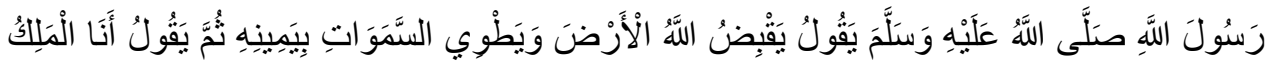

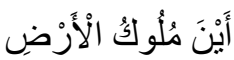

The Prophet Muhammad SAW said, "On the Day of Resurrection, Allah will hold the whole Earth and fold the Heaven with His right hand and say, 'I am the Sovereign: where are the kings of the earth?' ".43

From this hadith, it can be understood that the universe is folded so that the distances among celestial bodies do not exist and are united in the grasp of Allah. Under these circumstances, the universe's 'title' ends.

\section{Closing}

The creation of the heavens and the earth (the world, universum, cosmos) takes place by evolution, not timeless with 'kun fayakun'. The universe exists because Allah created it from nothing into existence (creation ex nihillo, minal' adam ilal $w u j u \bar{d}$ ). The first creation is in the form of non-existent initial matter, then becomes water or smoke then becomes objects and space between objects by dividing. It can be termed an explosion and its effects as subsequent events. The basis and commitment of God to create is love, conceptualized in advance, starting in time, not in time of duration of moving objects in the hole of the universe, but in God's time is non-gradually. That is why the state before creation was pitch black. Earth is part of the universe that entirely holy that can be used to worship God. After the heavens and the earth were laid out, and they are existing now, God declared himself the King of the Universe, and all submitted to Him. In synergy with the pillars of faith regarding to doomsday, the heavens and the earth will also end up being folded by Allah till they shrink, that is, the composition or layout of the entire material in the universe changes completely. The new form of the structure of the universe cannot be understood by humans.

\section{Bibliography}

Anonim, Al-Qur'ân Al-Karím, Departemen Agama Republik Indonesia: Sygma Examedia Arkanleema. Bandung, 2017.

${ }^{43}$ HR. Muslim: 4994, Bukhari: 4438. 
Danusiri

Anis, Ibrahim, (et all), al-Mu'jam al-Wasith. Istambul: Al-maktabah Al-Islamiyyah, II,[t.th.].

Al-Ashfahani, Ar-Raghib, Mufradât Alfâzz al-Qur'ân. Damsik-Beirut: Dar Al-QalamDar Al-Islamiyyah, 1992.

Al-Bukhariy al-Ju'fiy, Abi 'Abdullâh Muhammad bin Isma'íl bin Ibrâhím ibn alMughírah bin Bardizbah, Shahíh al-Bukhâriy, Semarang: Maktabah wa Mathba'ah Thaha Putra Semarang, [t.th.].

Al-Khatib, Muhammad Ajjaj, Ushul al-Hadís: 'Ulūmuhu wa Mushthalâhuh, Beirut: Dâr al-Fikr, 1975.

As-Sayuthi, Jalâl ad-Dín, Tadríb ar-Râwi fi Syarh\} Tadríb an-Nawawi, Mishr: Maktabah an-Naḥ̣ah, [t.th].

Asy'arie, Musa, Filsafat Islam: Sunnah Nabi Dalam Berpikir, Yogyakarta: LESFI [Lembaga Studi Filsafat Islam], 1999.

Ath-Thaḥhan, Maḥmūd, Taisír Mushthalâḥul Hadís, Beirut: Dar as-SaqafahalIslamiyyah, [t.th.].

Edwards, Paul, The Encyclopaedia og Philosophy, New York: Collier Macmillan Publishers, VII, 1972.

Gottscalk, Louis, Understanding History: a Primer of Historical Methode, translated by Nugroho Notosusanto entitled Mengerti Sejarah, Jakarta: UI Press, 1973.

Hornby, A.S. Oxford Advanced Learrning Dictionary of Current English, [t.t.:t.p., t.th.]. Ibn Mandhur, Jamâl ad-Dín Muhammad Ibn Mukarram al-Anshari, Lisan al-'Arab. Qahirah: Dar al-Mishriyyah li at-Ta'lif wa at-Tarjamah, 1990, XII, [t.th.].

Iqbal, Mohammad, The Reconstruction of Religious Thought in Islam, Lahore: Kitab Bavan, 1981.

Ismail, M.Syuhudi, Metodologi Penelitian Hadis Nabi, Jakarta: Bulan Bintang, 1991.

, Pengantar Ilmu Hadits [sic], Bandung: Angkasa, 1987.

Milles, Matthew B. \& A Michael Huberman, Qualitative Data Analysis, translated by

Tjetjep Rohandi entitled: Analisis data Kualitatif, Jakarta: Universitas Indonesia, 1992.

Muhadjir, Noeng, Metodologi Penelitian Kualitatif, Yogyakarta: Rakesarasin, 1994.

Nasution, Harus, Falsafah dan Mistisisme Dalam Islam, Jakarta: Bulan Bintang, 1978.

Rahman, Fazlur, Islam, Chicago-London: University of Chicago Press, 1966.

Runes, Dagobert de, Dictionary of Philosophy, Totowa-New Jersey: LittlefieldAdams \& Co., 1976.

Sayyid Quthb, Tafsir Fi Zhilalil Qur'an, X, [Indonesian Ed], Jakarta: Gema Insani, 2004.

Shalih, Shubhii 'Ulâm al-Hadís wa Mushthalâhuhu, Beirut:al-'Ilm al-Malayín, 1988.

Siswanto, Joko, Kosmologi Einstein, Yogyakarta: PT Tiara Wacana Yogya, 1996.

'Usman, Hasan, Manhaj al-Bah at-Târihiy, [t.tp]: Dar al-Ma'arif: 1976.

'Usman bin 'Abd ar-Rahmân Ibn Shalâh, Abu 'Amr, 'Ulum al-Hadís, (Al-Madinah alMunawwarah: al-maktabah al-'Ilmiyyah, 1972.

Webster's New Dictionary and Theasurus, USA: Geddest \& Grosset Ltd., 1990. 